\title{
ACTIVE LEARNING IN HIGHER EDUCATION: DEVELOPING PROJECTS IN PARTNERSHIP WITH INDUSTRY
}

\author{
José Dinis-Carvalho ${ }^{1}$, Sandra Fernandes ${ }^{2}$, Rui M. Lima ${ }^{1}$, Diana Mesquita ${ }^{3}$, \\ Cristina Costa-Lobo ${ }^{2}$ \\ ${ }^{1}$ Production and Systems Department, University of Minho (PORTUGAL) \\ ${ }^{2}$ Instituto de Neuropsicologia e Neurociências Cognitiva e Comportamental (INPP), \\ Universidade Portucalense (PORTUGAL) \\ ${ }^{3}$ Research Centre on Child Studies, University of Minho (PORTUGAL)
}

\begin{abstract}
Project Based Learning is an active learning approach with some good results perceived by students, academic staff and employers. A decade of experience and research at the Industrial Management and Engineering (IME) Integrated master programme at the University of Minho has provided strong evidence of its advantages and disadvantages. One of the PBL approaches being applied is based on projects in real contexts, where student teams must analyse and improve aspects of production systems in different companies in the region. The soft skills development as well as the attractiveness of such projects for students are common topics to be explored in such type of initiatives. The objective of this paper is to collect evidence on how such real context projects can be effective in developing specific technical knowledge on students. The technical knowledge covered in this article is based on the curricular unit "Production Systems Organization II" of the $7^{\text {th }}$ semester of the IME programme. Data collection was based on the application of questionnaire to students involved in this semester $(n=62)$. The results show that student perceptions on the effect of the project is, in average, considered "important" ( 4 in a Likert scale) and that the learning outcomes mostly influenced by the project are related to issues such as the nature of the project and the typology of the company. More complex production systems with complex production flows, high variety of products and more process steps together with more skilled management people, seem to bring better results in student's understanding of the learning outcomes developed with the project.
\end{abstract}

Keywords: Active Learning, Project Based Learning, University-Industry Collaboration, PBL in real context.

\section{INTRODUCTION}

This work follows several studies in which it is assumed that the involvement and commitment of higher education teachers in the implementation and monitoring of active learning strategies used by the students promotes their preparation for the transition to higher education to labour market, and that these pedagogical strategies constitute a success factor in this transition process (e.g. [1], [2], [3]). It is within this scope the implementation of pedagogical scenarios of Project Based-Learning, focusing on the tasks performed by the student, and teaching is understood as a learning support activity.

The Integrated Master course in Industrial Engineering and Management at the University of Minho collects ten years of experience in Project Based Learning (PBL) approaches with significant success. The main goal for the organizers of this PBL case is that students go through a rewarding experience, with high levels of engagement and where learning is very effective and significant. The PBL approach applied in the seventh semester at Integrated Master course in Industrial Engineering and Management (University of Minho) is focused in projects in real context in companies in the region; one company project is assigned to each one of the six teams of 10 or 11 students at the beginning of the semester; each team has to analyse a production system in the company basically in terms of its production organization, production planning and control system, information management, and ergonomics; the teams must then identify improvement opportunities, propose solutions for improvements, implement them and check the results; student teams end up with creative and very effective solution for companies in a very professional level. This paper aims to analyse the impact of the projects, projects developed in partnership with industry, on student learning, engagement and development of professional skills. Data collection is based on questionnaires, administered to 
students, and interviews, to teachers and company representatives, that were directly involved in the project.

\section{STUDENT PROJECTS IN PARTNERSHIP WITH INDUSTRY}

This study is based on a reality where advantages of the project work, project based learning, multidisciplinarity and university-industry collaboration, are all put together. This environment is designed to provide a very effective experience for students in order to develop technical and professional skills.

\subsection{Project Based Learning}

Although characterizations vary in the details, Project-Based Learning is typically considered an approach to teaching in which students respond to real-world requests or tasks through an extended inquiry process ([1], [4], [5], [6], [7], [8], [9], [10]). PBL organizes learning around projects and involves the students in authentic situations where they can explore and apply the subject matter to problems that are complex and relevant to the professional practice for which they are preparing [11]. The characteristics of PBL are developing students' thinking skills, allowing them to have creativity, encouraging them to work cooperatively, and leading them to access the information on their own and to reveal this information ([4], [12], [13]). The circumstances of Project-Based Learning involve the student in experimentation and work in association, in successive and integrated stages, stages that involve the interaction between the new material and the pre-existing cognitive structure in the student, resorting to learning by discovery and maximum intentionality of the intervention of cognitive processes. Project-Based Learning is an individual or group activity that goes on over a period of time, resulting in a product, presentation, or performance. It typically has a time line and milestones, and other aspects of formative evaluation as the project proceeds. From a research point of view, ProjectBased Learning is supported by work in: constructivism; situated learning theory, cooperative Learning, problem solving, peer instruction, problem-based learning. Project-Based Learning and Problem-Based Learning are two distinct approaches to learning. In Project-Based Learning, students have a great deal of control of the project, they will work on and what they will do in the project. The project may or may not address a specific problem. In Problem-Based Learning, a specific problem is specified by the course instructor, and students work individually or in teams over a period of time to develop solutions to this problem. Project-Based Learning is learner centred. Students have a significant voice in selecting the content areas and nature of the projects that they do. There is considerable focus on students understanding what it is they are doing, why it is important, and how they will be assessed. Indeed, students may help to set some of the goals over which they will be assessed and how they will be assessed over these goals. All of these learner-centred characteristics of PBL contribute to learner motivation and active engagement. A high level of intrinsic motivation and active engagement are essential to the success of a Project-Based Learning lesson. Project Based Learning's circumstances aim to achieve a profound approach to student learning, fostering the emergence of circumstances of understanding, application, analysis, synthesis, evaluation and meaning-seeking ([1], [2]). From the teacher's side, this pedagogical strategy: brings out the structure of the topic or subject explicitly; elicits a positive response, by questioning or presenting problems; is building on what students already know; confronts and eradicates students' misconceptions; assesses for knowledge structure rather than independent facts; encourages a positive working atmosphere, so students can make mistakes and learn from them; emphases depth of learning, rather than breadth of coverage; uses teaching and assessment methods that support the explicit aims and objectives of the course.

\subsection{University-Industry Collaboration}

The collaboration process between universities and industries is not new. Nevertheless, recently, the European agenda has been reinforcing the relevance of this collaboration, in terms of Higher Education innovation at different levels (policies, teaching and learning, research, etc.).

A study carried out by Science-to-Business Marketing Research Centre (S2BMRC) for the DG Education and Culture at the European Commission (EC) during 2010 and 2011, shows that the common results attributed to successful University Business Cooperation (UBC) "include improving the education and future job prospects of students, the research conducted within the $\mathrm{HEI}$ and the transfer of knowledge and research to the community" [14]. The researchers also defined eight different approaches in which universities and industries cooperate: 1. Collaboration in research and 
development (R\&D), 2. Mobility of academics, 3. Mobility of students, 4. Commercialization of R\&D results, 5. Curriculum development and delivery, 6. Lifelong Learning (LLL), 7. Entrepreneurship and 8. Governance.

The same authors developed another study in which 30 case studies were analysed, in order to identify the nature of collaboration between universities and industries, difficulties, advantages, amongst other issues [15]. Only one case is related to "Curriculum development and delivery", linked with the development of business ideas of students supported by funding mechanisms that are difficult to maintain. This confirms that studies concerning University and Industry Cooperation are still reduced and, consequently, needed. On the one hand, universities are preparing students for these industries, and on the other hand, industries can benefit from this interaction, exploring the opportunity to improve and innovate their products or processes. In order to create sustainable interactions, it is necessary to study different models of projects, define dimensions of analysis and evaluate these models.

\subsection{Effective Learning with projects in industry context}

For a long time, universities and industry had difficulties maintaining long-term interactions in projects involving teams of students solving real problems, where students are able to experience the professional practice.

The integration of practice in educational models has been explored with different focus [16]: (1) integrating practice periods with integral formation objectives; (2) alternating separated training contexts; (3) promoting employability through the development of professional competences and mutual knowledge of agents. For the author, the learning contexts in which teachers, students and external professional agents are engaged in the integration of curriculum dimensions (objectives, activities, contents, resources, and assessment) is called Practicum [17]. Project-based learning models in collaboration with industries might be considered an example of practicum in the curriculum and, for that reason, an added-value for students' learning process.

Engineering problems can be more meaningful if they can be based on companies' real problems [18]. In other words, a real context provides an opportunity for student to mobilize the contents and knowledge developed in the different courses, in order to find out solutions for problems faced by the industry [19]. With this approach, students become aware about the importance of what they are learning in the classroom, because they have the opportunity to link those contents in an interdisciplinary way in order to solve problems. Furthermore, students learn a set of issues that is more difficult to be able to develop in a classroom environment, such as communicating with different professionals, developing and exploring engineering competences. In short, the competences developed in this type of environment will contribute to transform theory into practice, reinforcing the understanding of theory, and developing transversal competences, like teamwork, project management, critical thinking, problem solving and communication skills [20], [21], [22].

\section{CONTEXT OF THE STUDY}

The case that is reported in this paper is based on a Project-Based Learning approach that has been developed to deal, in the best way, with the problem of having 6 large teams of students performing a project in different companies during one semester and covering several different curricular units.

\subsection{PBL at Industrial Management and Engineering Integrated Master Course}

Since 2004/05 the Industrial Engineering and Management Integrated Master (IEM-IM) at University of Minho, Portugal, had implemented project-based learning approaches in three out of ten semesters of the program $\left(1^{\text {st }}, 7^{\text {th }}\right.$ and $8^{\text {th }}$ semesters). Several studies were carried out in this context in the past 10 years and the results reinforce the relevance of project-based learning for preparation for professional practice [18], students' engagement [23], teachers' role [24], curriculum innovation [25], amongst other issues.

The IEM-IM PBL general model is presented in Fig. 1 and it is possible to identify the interdisciplinary nature of the projects. The different circles in Fig. 1 mean that courses 1, 2, 3 through $n$ are integrated in the project (project supporting courses) while course $A$ is not integrated in the project. In each semester project a set of specific courses are integrated in the project, and its teachers give support to the students' work. In other words, students' teams need to mobilize the content and knowledge 
provided in the context of each course, in order to develop solutions for the problem driven by the project. In the seventh semester, students and teachers interact with industrial companies trying to solve real problems, while developing the courses' required competences.

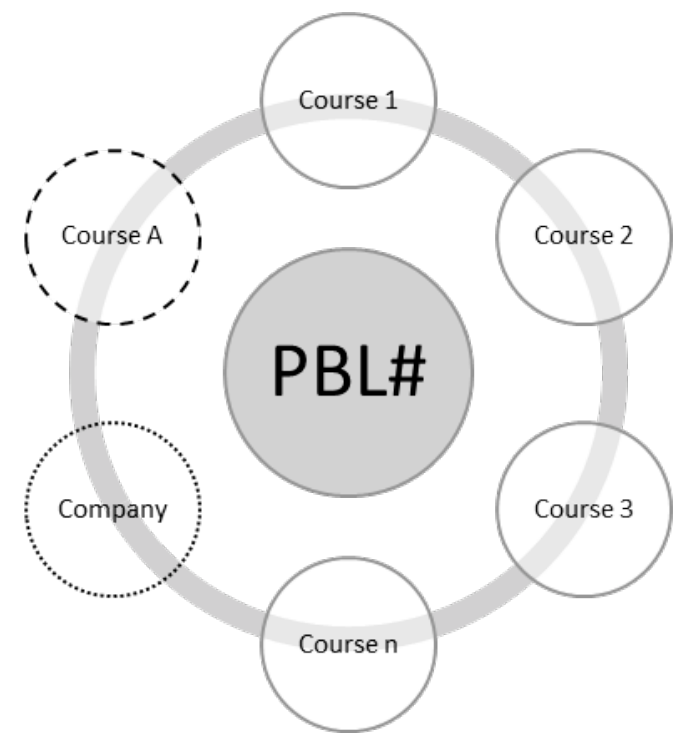

Figure 1 - IEM-IM PBL General Model.

This work focuses on the project-based learning of the $7^{\text {th }}$ semester of the IEM-IM program. This project involves five project-supporting courses, namely: (i) Production Systems Organization II (OSP2), (ii) Production Information Systems (SIP), (iii) Simulation (SIM), (iv) Ergonomic Studies for Workstations (EEPT) and (v) Production Integrated Management (GIP). The added-value of this project is the opportunity to be developed in a real professional context. Previous studies shows the importance of a UBC approach regarding students' learning experience [26], [27].

Each students' team develop their project in a company (six companies are involved) during the whole semester (17 weeks). It is possible to identify two main stages of the project:

1 Analysis and diagnosis of the company's production system - in the context of each of the five project supporting courses, student teams use different contents and analysis methodologies/tools to evaluate the production system and identify problems.

2 Development of proposals of improvement - the teams must develop improvement proposals, using the different intervention tools/methodologies provided by the project supporting courses, in order to deal with at least one of the identified problems.

During the semester, the project is supported by a coordination team composed by the teachers of the project supporting courses, the team tutors and the researchers. Furthermore, professionals from the six companies involved also support the project (company tutors), particularly during the weekly visit that the teams need to do in order to understand the industrial process and to collect information. The companies can be from several types of industry and some of them have participated more than once.

Since 2005, 12 editions of this project involved more than 20 companies, which engaged more than 400 students. In the 2016/17 edition there are 62 students distributed by six project teams of 10 to 11 students. Thirty-four of the sixty-two are female students and twenty-eight are male students. The great majority of the students' ages range from 21 to 22 years old.

\subsection{Production Systems Organization II Course Unit}

This study focuses exclusively on one of the curricular units that integrates the $7^{\text {th }}$ semester of the IME Programme - "Production Systems Organization II" (PSOii). This curricular unit, that is going to be referred in this article as PSOii, is a Project Supporting Course in the PBL approach, as classified by [28]. The definition of each project results from a previous negotiation between the company and the PBL organizers. On the one side, the PBL coordination team tries to define projects that can match as much as possible all the learning outcomes listed in the supporting courses and, on the other side, the company representatives tries to define the project that better fulfils their current objectives. In the 
limit, this can result that one student project may cover a specific set of learnings outcomes that is completely different from the set of learning outcomes covered in the other student project.

The PSOii curricular unit plays a key role in the PBL approach presented in this paper since most companies are open to find improvement opportunities in their production systems. Since lean manufacturing is the main focus of PSOii and because most companies are now willing to implement lean based solutions in their productions systems, a large set of learning outcomes are expected to be reached through PSOii. The learning outcomes of PSOii curricular unit that are considered in this study include the following topics:

- Topic 1 - Pull production (pull production concept, two-bin-systems, one-piece-flow, kanban systems, pull production influence in the reduction of waste, pull production influence in production performance);

- Topic 2 - Analyses and diagnosis of production systems (Value Stream Mapping, Waste Identification Diagrams, Multimoment analysis, Waste identification, Identification of improvement opportunities, identification of lean tools for improvement opportunities);

- Topic 3 - Continuous improvement (PDCA technique, Team boards, Visual management, respect for people, the role of continuous improvement in the waste reduction and production performance);

- Topic 4 - Key Performance Indicators (Productivity, Throughput time, Labour utilization, Overall Equipment Effectiveness, Value Added Ratio, The role of this KPI in the business performance);

- Topic 5 - Role of inventory and setup times in the production (Inventory impact in production performance, setup times in the production performance);

- Topic 6 - Human factors and team work in production performance (the role of people in the production performance, role of team work in production performance and leadership styles in production performance).

\section{METHODOLOGY}

The objective of the study is to analyse student perceptions in regard to the importance of the projects carried out in the industry context and their role in achieving the expected learning outcomes of the PSOii curricular unit. To reach this goal, a questionnaire was developed to collect information from students on how the project carried out by each team contributed to develop the learning outcomes defined for PSOii curricular unit, listed in the previous section.

The questionnaire required each team to indicate, based on a Likert scale, the level of importance given to the project in order to develop each learning outcome stated. In total, 6 topics and their related concepts were explored. Students were asked to rate the level of importance given to the project in order to understand each concept presented, based on the following scale: 1 (not significant); 2 (it was unimportant); 3 (moderately important); 4 (it was important) and 5 (it was very important). An example: "Indicate the level of importance (1 to 5 ) that you assign to the project in order to develop the understanding of the one-piece-flow concept (Pull Production).

The participants in the study included 62 students, divided in 6 project teams. Each team included 10 to 11 team members. The great majority of the students' ages ranged from 21 to 22 years old. In terms of gender, 34 are female and 28 are male students. The following table presents a brief description of the student teams, the company sector and the project's objectives. 
Table 1. Description of Students Projects.

\begin{tabular}{|c|c|c|}
\hline Student Team & Company Sector & Project Objectives \\
\hline $\begin{array}{c}\text { Team } 1 \\
\text { (11 students) }\end{array}$ & Stove Manufacturer & $\begin{array}{l}\text { To analyse and improve the assembly line, pre-assembly } \\
\text { as well as the internal logistic system }\end{array}$ \\
\hline $\begin{array}{c}\text { Team } 2 \\
\text { (10 students) }\end{array}$ & $\begin{array}{l}\text { Textile Fabrics } \\
\text { Manufacturer }\end{array}$ & $\begin{array}{l}\text { To analyse and improve the transport and storage of rolls } \\
\text { of fabrics, in the connection between the weaving cells } \\
\text { and impregnation }\end{array}$ \\
\hline $\begin{array}{c}\text { Team } 3 \\
\text { (10 students) }\end{array}$ & Tool Manufacturer & $\begin{array}{c}\text { To analyse and improve parts of the internal logistic } \\
\text { system }\end{array}$ \\
\hline $\begin{array}{c}\text { Team } 4 \\
(10 \text { students })\end{array}$ & Metal Construction & $\begin{array}{l}\text { To analyse and improve the welding area in terms of } \\
\text { layout and flow of materials }\end{array}$ \\
\hline $\begin{array}{c}\text { Team } 5 \\
\text { (11 students) }\end{array}$ & Wiring systems & $\begin{array}{l}\text { To analyse and improve the Overall Equipment } \\
\text { Effectiveness of the cutting machines and the flow of } \\
\text { materials along the shop floor. }\end{array}$ \\
\hline $\begin{array}{c}\text { Team } 6 \\
\text { (10 students) }\end{array}$ & Plastic extrusion & $\begin{array}{l}\text { To analyse and improve the production systems as a } \\
\text { whole in terms of layout and production flows. }\end{array}$ \\
\hline
\end{tabular}

For data analysis, descriptive statistics (average results) was used to describe and discuss the quantitative data achieved in the questionnaires collected from students. This analysis was complemented with simple graphics that allowed a better understanding and comparison of results of each team in regard to the 6 topics.

\section{RESULTS}

The overall results from the questionnaires are presented in Fig. 2. For each topic (e.g. "Pull Production"), the graphic shows the average results of each team in the group of questions regarding that topic (please see the items in Tab. 2). In some way, the graphic shown on Fig. 2 presents the average perception of students regarding the influence of their project in the development of knowledge based on each topic (set of learning outcomes related to a specific topic), which is, in general, very positive. This is, students believe that the project contributes, in a positive way, to learn and develop the competencies related to the learning outcomes of the course.

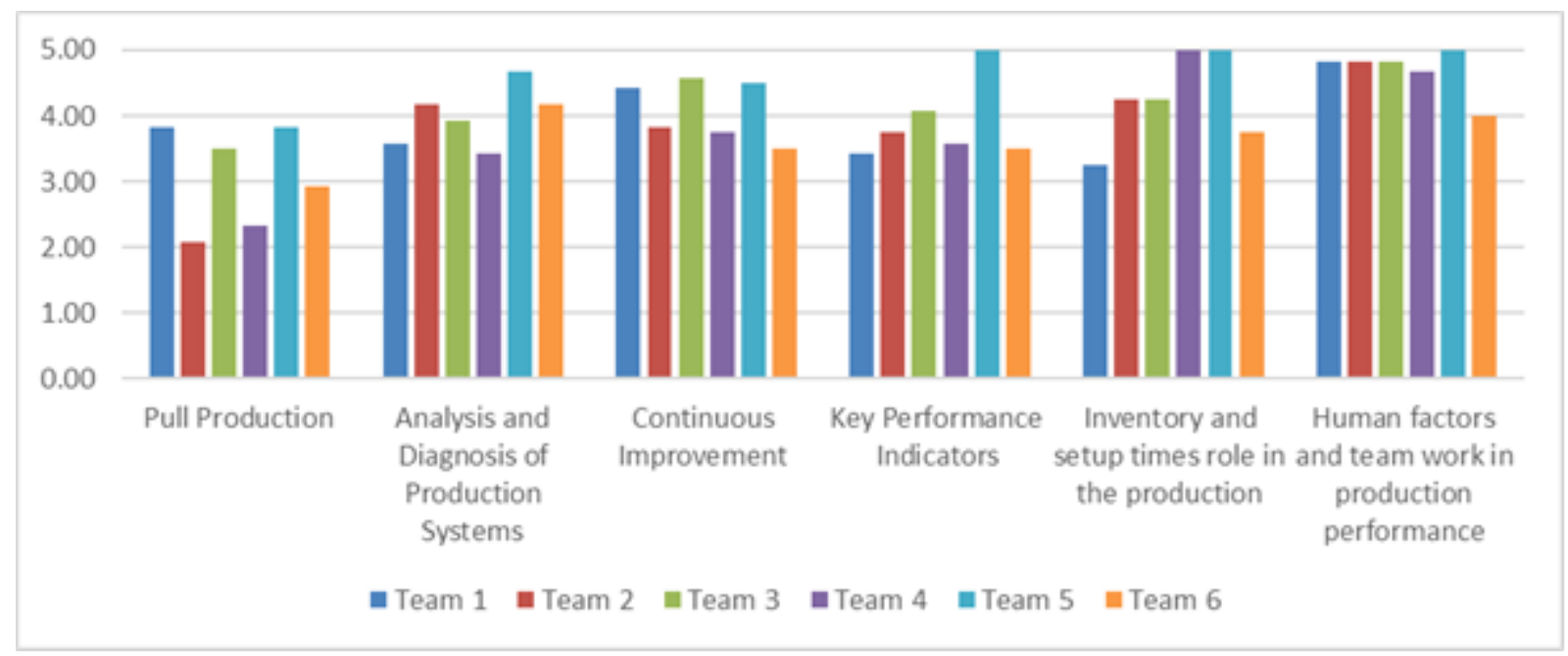

Figure 2 - Overall Results of the Questionnaire.

Regarding the first topic "Pull Production", the differences of the results from different teams are evident. Team 2 and Team 4 perceived their project as "it was unimportant" in developing knowledge in that topic. The reason is that in their projects the teams were not involved in any aspects of pull 
production. In team 2, the group was more concerned in analysing and improving the transport and storage (company: Textile Fabrics Manufacturer) and team 4 was working in a production area very "process oriented" (company: Metal Construction), where managers had management point of view more focused in equipment utilization rather than having flow concerns. On the other hand, team 1, 3 and 5 recognized a more "important" role of the project in developing pull production knowledge since their projects took place in a production environment more product oriented, where production flow plays an important role in their production performance (companies: Stove Manufacturer, Tool Manufacturer, Wiring systems). Interestingly this was the only topic with classification bellow 3 (moderate important) and that is because few pull production practices are commonly found in industry.

Another result easily observed in Fig. 2 is the low variability of the team's recognition of the project role in the development of knowledge related to "Human factors and team work in production performance". All teams rated values above 4 (it was important) and most of them very close to 5 (it was very important). This result may be understandable since this type of awareness cannot be built by reading books or listening to teachers. You need to be in the real context in order to grasp this type of knowledge.

When analysing the overall effect of the project in the development of the knowledge covered in PSOii curricular unit based on each team's perceptions, the results show (see averages in Tab. 2) that team 6 is the team with lowest rating (with a value of 3.64) and team 5 with the highest result (4.67). Team 6 carried out the project in a plastic extrusion shop floor with low variety of products and few machines, where the main focus is on machine utilization and warehouse management. The quite simple production system in terms of production routes and low variety of products associated to the classic management approach adopted in the company may have narrowed the team's challenges.

Table 2. Average Team Results Obtained for Each Topic.

\begin{tabular}{lccccccc}
\hline \multicolumn{1}{c}{ Topics } & Team 1 & Team 2 & Team 3 & Team 4 & Team 5 & Team 6 & Average \\
\hline Pull Production & 3.83 & 2.08 & 3.50 & 2.33 & 3.83 & 2.92 & $\mathbf{3 . 0 8}$ \\
$\begin{array}{l}\text { Analysis and Diagnosis of } \\
\text { Production Systems }\end{array}$ & 3.58 & 4.17 & 3.92 & 3.42 & 4.67 & 4.17 & $\mathbf{3 . 9 9}$ \\
$\begin{array}{l}\text { Continuous Improvement } \\
\text { Key Performance Indicators }\end{array}$ & 4.42 & 3.83 & 4.58 & 3.75 & 4.50 & 3.50 & $\mathbf{4 . 1 0}$ \\
$\begin{array}{l}\text { Inventory and setup times role } \\
\text { in the production }\end{array}$ & 3.25 & 4.25 & 4.25 & 5.00 & 5.00 & 3.75 & $\mathbf{4 . 2 5}$ \\
$\begin{array}{l}\text { Human factors and team work } \\
\text { in production performance }\end{array}$ & 4.83 & 4.83 & 4.83 & 4.67 & 5.00 & 4.00 & $\mathbf{4 . 6 9}$ \\
\multicolumn{1}{c}{ Average } & $\mathbf{3 . 8 9}$ & $\mathbf{3 . 8 2}$ & $\mathbf{4 . 1 9}$ & $\mathbf{3 . 7 9}$ & $\mathbf{4 . 6 7}$ & $\mathbf{3 . 6 4}$ & $\mathbf{4 . 0 0}$ \\
\hline
\end{tabular}

On the other hand, team 5 carried out the project in a much more diverse and complex production system with several machine types, assembly lines, pre-assembly processes, multiple routes and large variety of products. In fact, from the results obtained, team 5 perceived their project as contributing with top mark (5 - it was very important) to the last three topics (topic 4,5 and 6 ) more than all other teams. On the topic 2 (Analyses and diagnosis of production systems) team 5 also gave the highest mark probably because the complexity of the production system and also because of the open attitude of the production manager towards the team's work and proposals.

Since topic 5 (Role of inventory and setup times in the production) is a key concept in industry management and engineering field and also because it was the topic with the second highest mark (4.25 in average) it requires some attention. Although team 4 showed the second lowest average value in perceiving the importance of the project in building knowledge (with 3.79 mark) the same team recognized that the project was "very important" (5 mark) in contributing to the understanding of a key issue which is how the inventory and setup times influence the production performance. The main reason for that may be the fact that this group had to focus on the high levels of inventory and proposed a solution to reduce greatly the needed area by reducing that inventory. Most inventory was justified by setup times by the managers, but the team actually ended up convincing the managers in implementing their proposal. All the necessary work to build such proposal was the key, in our 
understanding, for the team to develop deep knowledge in the impact of inventory and setup time in production performance.

The topic with lowest rating by students was topic "Pull Production". To understand this in a deeper way, table 3 shows the specific average results of each concept within pull production topic. The project was perceived by students in average as "important" in the development of understanding of two bin systems and Kanban systems (both values of 2.72). In fact, neither the concept of "Two Bin System" nor the concept of "One-Piece-Flow" was actually in use in any of the companies involved in these projects. Only team 1 and 5 had some concerns on applying that in their projects.

Table 3. The Questionnaire Items Average Results in the Pull Production Topic.

\begin{tabular}{lc}
\hline \multicolumn{1}{c}{ Pull Production Items in the Questionnaire } & Average of All Teams \\
\hline I fully understood the concept of Pull Production & 3.09 \\
I fully understood the concept of two bin systems & 2.72 \\
I fully understood the concept of One-piece-flow & 3.27 \\
I fully understood the concept of kanban system & 2.72 \\
I fully understood the importance of pulled production in reducing & 3.27 \\
production waste & \\
I fully understood the importance of pull production in the performance of & 3.00 \\
\hline
\end{tabular}

Contrary to the topic with less positive average results, there is the topic with the highest rating, the topic "Human factors and team work in production performance" (see Tab. 4). Among the 3 items included in the questionnaire in this topic, the role of teamwork in the production performance was recognized in que questionnaire as the item upon which the project played the most relevant part. This was somehow unexpected and interesting since the human factors, team work and leadership, are not very highlighted learning outcomes in the curricular unit and they are not expected to be explored by students in the project.

Table 4. The questionnaire items average results in the Human factors and team work topic.

\begin{tabular}{lc}
\hline Human Factors and Team Work in Production Performance & $\begin{array}{c}\text { Average of All } \\
\text { Teams }\end{array}$ \\
\hline I fully understood the role of people in the production performance & 4.73 \\
I fully understood the role of teamwork in the production performance & 4.82 \\
I fully understood the role of the leadership in the production performance & 4.45 \\
\hline
\end{tabular}

Looking at the overall average of every team in each question obtained in the questionnaire, the result is the round number 4.00 (see table 2). This overall average can be the interpreted as a positive recognition that the project carried out by students in the industry context is important to develop the overall learning outcomes defined in the PSOii curricular unit.

\section{CONCLUSIONS}

This paper aims to collect evidence on how projects carried out in real contexts, as the ones reported in this study, can be effective in developing specific technical knowledge on student learning. The learning approach is a project based learning environment where the projects are carried out in an industry by student teams during one semester. The projects are planned to cover several curricular units of the current semester but, in this study, the focus is in a particular set of learning outcomes defined for a curricular unit where lean concepts and tools are the main focus. The 29 items in the questionnaire given to students are grouped into 6 different topics which focus on the main learnings outcomes defined for the curricular unit called "Production Systems Organization II".

The results show that student perceptions on the effect of the project is, in average, considered "important" (4 in a Likert scale) for the development of the defined learning outcomes of that particular 
curricular unit. Moreover, the learning outcomes influenced mostly by the project are related to issues such as the nature of the project and the typology of the company. There are strong evidences that projects carried out in more complex production systems with complex production flows, high variety of products and more process steps together with more skilled management people, seems to bring better results in the development of student learning outcomes resulted from the project.

An interesting outcome of this study is that the learning outcomes related to the effect of the human factors, team work and leadership in production performance were recognised by students as being effectively developed in the project. In fact, those learning outcomes had, in average, the highest ratings by student teams, although these topics are not very explored in the classes.

In future work, a study will be carried out in order to compare the effectiveness of the classes with the effectiveness of the project. The idea is to identify what learning outcomes are more effectively developed in the classroom learning environment and what learning outcomes are more effective when learned based on a project approach.

\section{ACKNOWLEDGEMENTS}

This work has been supported by COMPETE: POCI-01-0145-FEDER-007043 and FCT - Fundação para a Ciência e Tecnologia within the Project Scope: UID/CEC/00319/2013.

\section{REFERENCES}

[1] Costa-Lobo, C., Taveira, M. C. \& Duarte, M., "O papel da aprendizagem cooperativa na adaptação à carreira no ensino superior". JLBE09/Jornadas luso-brasileiras de ensino e tecnologia em engenharia (pp. 692). Porto: Instituto Superior de Engenharia do Porto, 2008.

[2] Escudeiro, N., Escudeiro, P., Costa-Lobo, C., Duarte, M., Assche, K. V., Roth, H. \& Sahm, S., Outcomes, Challenges and Benefits in MUTW, White Book. Amazon, Barnes \& Noble, 2010.

[3] Martins, C., Couto, P., Fernandes, M., Bastos, C., Costa-Lobo, C., Faria, L. \& Carrapatoso, E., PCMAT - Mathematics Collaborative Learning Platform. 9th Conference on Practical Applications of Agents and Multi-Agent Systems, pp. 01 - 10, 2011.

[4] Tawfik, M., Sancristobal, E., Martín, S., Gil, C., Pesquera, A., Losada, P., Díaz, G., Peire, J., Castro, M., García-Zubia, J., Hernández, U., Orduña, P., Angulo, I., Costa-Lobo, C., Marques, M. A., Viegas, M. C. \& Alves, G. R, VISIR Deployment in Undergraduate Engineering Practices. Proceedings 41st ASEE/IEEE Frontiers in Education Conference (FIE 2011), USB version, IEEE Catalog Number: CFP11FIE-USB. ISBN: 978-1-61284-467-1, 2011.

[5] M. C. English and A. Kitsantas, "Supporting student self-regulated learning in problem and project-based learning," Interdisciplinary Journal of Problem-Based Learning, vol. 7, no. 2, pp. 128-150, 2013.

[6] J. W. Thomas and J. R. Mergendoller, "Managing project-based learning: Principles from the field," presented at the Annual Meeting of the American Educational Research Association, New Orleans, LA, 2000.

[7] M. Bradford, "Motivating students through project-based service learning," T.H.E. Journal, vol. 32, no. 6, p. 29, 2005.

[8] B. K. Hofer, "Motivation in the college classroom," in McKeachie's teaching tips: Strategies, research, and theory for college and university teachers, 12th ed., W. J. McKeachie and M. Svinicki, Eds., Boston: Houghton Mifflin, pp. 140-150, 2006.

[9] D. K. Meyer, J. C. Turner, and C. A. Spencer, "Challenge in a mathematics classroom: Students' motivation and strategies in project-based learning," The Elementary School Journal, vol. 97, no. 5, pp. 501-521, 1997.

[10] S. Wolk, "Project-based learning: Pursuit with a purpose," Education Leadership, vol. 52, no. 3, pp. 42-45, 1994. [10] H. S. Barrows, "Problem-based, self-directed learning," Journal of the American Medical Association, vol. 250, no. 22, pp. 3077-3080, 1983.

[11] R. M. Capraro and S. W. Slough, Project-Based Learning: An Integrated Science, Technology, Engineering, and Mathematics (STEM) Approach, The Netherlands: Sense Publishers, 2009. 
[12] J. Biggs, Teaching for Quality Learning at University, Buckingham, UK: Open Univ. Press, 2000.

[13] R. E. Yager, "Power of purpose in reforms in science education and the impossibility of transferring knowledge," presented at 2002 Sino-America Science Education International Conference on Teaching Colleges, Taiwan Taipei, 2002.

[14] Davey, T., Baaken, T., Muros, V. G., \& Meerman, A. (2011). 30 Best Case Studies of Good Practice in the Area of UBC within Europe. In Todd Davey, T. Baaken, M. Deery, \& V. G. Muros (Eds.), Retrieved from http://www.ub-cooperation.eu/index/casestudy

[15] Davey, T., Baaken, T., Muros, V. G., \& Meerman, A. (2011). The State of European UniversityBusiness Cooperation Final Report - Study on the cooperation between Higher Education Institutions and public and private organisations in Europe. In Retrieved from http://www.ubcooperation.eu/pdf/final_report.pdf

[16] Zabalza, M. (2013). El Practicum y las Prácticas en Empresas en la Formación Universitaria. Madrid: Narcea.

[17] Zabalza, M. (2011). El Practicum en la formación universitaria: estado de la cuestión (Practicum in higher education: state of the art). Revista de Educación(354), 21-43.

[18] Kolmos, A., \& Holgaard, J. E. (2010). Responses to Problem Based and Project Organised Learning from Industry. International Journal of Engineering Education, 26(3), 573-583.

[19] Lima, R. M., Mesquita, D., \& Flores, M. A. (2014). Project Approaches in Interaction with Industry for the Development of Professional Competences. IIE Annual Conference and Expo 2014 - Industrial and Systems Engineering Research Conference (ISERC), Montréal, Canada, 31/05/2014 - 03/06/2014. ISBN: 978-098376243-0.

[20] Markes, I. (2006). A review of literature on employability skill needs in engineering. European Journal of Engineering Education, 31(6), 637-650.

[21] Passow, H. J. (2012). Which ABET Competencies Do Engineering Graduates Find Most Important in their Work? Journal of Engineering Education, 101(1), 95-118.

[22] Mesquita, D., Lima, R. M., \& Flores, M. A. (2013, 8-9 July 2013). Developing professional competencies through projects in interaction with companies: A study in Industrial Engineering and Management Master Degree. Proceedings of Fifth International Symposium on Project Approaches in Engineering Education (PAEE'2013): Closing the Gap between University and Industry, Eindhoven, The Netherlands, [1-7] ID103.

[23] Fernandes, S., Mesquita, D., Flores, M. A., \& Lima, R. M. (2014). Engaging students in learning: findings from a study of project-led education. European Journal of Engineering Education, 39 (1), 55-67.

[24] Alves, A., Sousa, R.M., Moreira, F., Carvalho, M. A., Cardoso, E., Pimenta, P., Malheiro, T., Brito, I., Fernandes, S., Mesquita, D. (2016). Managing PBL difficulties in an Industrial Engineering and Management program. Journal Industrial Eng. and Management, 9(3), 73-89.

[25] Mesquita, D., Lima, R. M., Flores, M. A., Marinho-Araújo, C., \& Rabelo, M. (2015). Industrial Engineering and Management Curriculum Profile: Developing a Framework of Competences. International Journal of Industrial Engineering and Management, 6(3), 121-131.

[26] Lima, Rui M., Diana Mesquita, José Dinis-Carvalho, and Rui M. Sousa. 2015. "Promoting the Interaction with the Industry through Project-Based Learning." In Seventh International Symposium on Project Approaches in Engineering Education (PAEE'2015), part of International Joint Conference on the Learner in Engineering Education (IJCLEE 2015), edited by Natascha van Hattum-Janssen, Rui M. Lima, Dinis Carvalho, Sandra Fernandes, Rui M. Sousa, Francisco Moreira, Anabela Alves, Diana Mesquita and Nestor A. Arexolaleiba, 198-205. San Sebastian, Spain: University of Minho.

[27] Lima, R. M., Dinis-Carvalho, J., Campos, L. C. d., Mesquita, D., Sousa, R. M., \& Alves, A. (2014, 28-29 July 2014). Projects with the Industry for the Development of Professional Competences in Industrial Engineering and Management. Paper presented at the Sixth International Symposium on Project Approaches in Engineering Education (PAEE'2014) (pp. ID13[1-11]), Medellin, Colombia.

[28] Powell, P. C., \& Weenk, W. (2003). Project-led engineering education. Utrecht: Lemma. 